\title{
ASPIRASI MAHASISWA FAKULTAS ILMU SOSIAL UNIVERSITAS NEGERI MAKASSAR TENTANG WACANA GBHN DITINJAU DALAM PERSPEKTIF IDEOLOGI PEMBANGUNAN
}

\author{
A. Aco Agus, Sangkala Ibsik, Firman Muin
}

Fakultas Ilmu Sosial, Universitas Negeri Makassar

\begin{abstract}
ABSTRAK
Wacana untuk mengembalikan GBHN perlu mendapatkan informasi tanggapan dan aspirasi dari kalangan mahasiswa sebagai warga kampus yang turut berkewajiban dan bertanggung jawab atas pelaksanaan pembangunann nasional Indonesia. Pemasalahan pokok GBNH adalah perlu tidaknya dihidupkan kembali sebagai pedoman dan pola dasar pembangunan nasional Indonesia. Rumusan masalah yang dikaji dalam penelitian ini adalah (1) bagaimna kondisi aspirasi mahasiswa FIS UNM tentang wacana dikembalikannya GBHN sebagai pedoman dan pola dasar pembangunan nasional Indonesia; (2) seberapa besar/tinggi tingkat aspirasi mahasiswa yang mendukung kembalinya GBHN sebagai pedoman dan pola dasar pembangunan. Tujuan penelitian ini adalah (i) untuk mengetahui kondisi aspirasi mahasiswa tentang wacana kembalinya GBHN; (ii) untuk mendapatkan data tinggi rendahnya aspirasi mahasiswa tentang dikembalikannya GBHN. Penelitian ini menggunakan pendekatan/metode deskriptif kualitatif dengan teknik pengumpulan data berupa kuesioner, wawancara dan fokus group discussion.

Hasil penelitian ini menunjukkan (1) kondisi aspirasi mahasiswa FIS UNM menunjukkan respon yang sangat positif dan kesungguhan hati yang kuat mendukung kembali dihidupkannya GBHN, mahasiswa sangat memahami hakekat tujuan, isi, manfaat dan kelebihan suatu GBHN dan memahami siapa yang selayaknya menyusun, membuat, menetapkan, melaksanakan dan mempertanggung jawabkan GBHN. (ii) tingkat aspirasi mahasiswa dalam kategori sangat tinggi (mencapai 91\%) untuk mendukung dikembalikannya GBHN sebagai pedoman dan pola dasar pembangunan nasional Indonesia.
\end{abstract}

Kata Kunci: Kondisi, Aspirasi, Wacana GBHN

\section{PENDAHULUAN}

Rancangan Pembangunan Jangka Menengah dan Panjang (RPJMP) ataupun Garis-garis Besar Haluan Negara (GBHN), merupakan merupakan pedoman, visi, peta jalan, arah ataupun target pembangunan Nasional yang sangat vital, strategis guna mencapai tujuan pembangunan nasional yang tepat sasaran, tepat waktu, produktif, sistematik, dan terukur. Dalam RPJMP dan GBHN terdapat tujuan, visi, misi, progrm, terget, sasaran, prioritas dan azas serta landasan yang diselengagarakan secara berlanjut dan berkesinambungan. Pada era reformasi ini berkembang wacana untuk menghidupkan kembali GBHN sebagai pedoman dan pola dasar pembangunan nasional Indonesia. Disadari bahwa wacana ini muncul bukan tanpa alasan dan 
134|Ad'ministrare, Vol. 3 No. 2, 2016

pertimbangan, sebab GBHN sebagai pedoman pola dasar pembangunan pernah diterapkan dalam upaya pembangunan nasional Indonesia.

GBHN memiliki urgensi dan arti yang sangat strategis dalam ideologi dan pelaksanaan pembangunan nasional Indonesia. Wacana dikembalikannya GBHN sebagai pedoman dan pola dasar pembangunan nasional Indonesia, saat ini ramai dan hangat diperbincangkan terutama oleh kalangan birokrasi dan akademisi. Permasalahan pokok yang timbul adalah bagaimana tanggapan para akademisi (mahasiswa) sebagai WNI yang berkecimpun dalam kampus yang mempunyai hak, kewajiban dan tanggung jawab dalam rangka penyelenggaraan pembangunan nasonal Indonesia.

\section{KAJIAN TEORI}

\section{Hakekat GBHN}

Sejak tahun 2007, istilah GBHN tidak lagi dipakai sebagai acuan pembangunan nasional Indonesia, digantikan dengan Rencana Pembangunan Jangka Panjang Nasional (RPJPN). RPJPN yang berdurasi 20 tahunan disahkan melalui UU Nomor 17 tahun 2007. RPJPN merupakaan perencanaan pembangunan yang bersifat praktis dan detail, disusun dan dilaksanakan oleh pemerintah sebagai eksekutif. Dibandingkan dengan GBHN, RPJPN lebih fleksibel dalam arti jika terjadi perubahan kondisi bangsa, RPJPN dapat merubah seluruhnya.

GBHN sebagai produk birokrasi pemerintahan yang menjadi kekuatan dalam menjalankan pembangunan nasional secara profesional. Miftah Thoha (2010, p.155) mengemukakan, bahwa pejabat birokrasi yang terlatih secara profesional mempunyai kekuatan tersendirisebagai suatu pejabat yang permanen. Birokrasi bukan merupakan partisan politik, akan tetapi karena keahliannya mempunyai kekuatan untuk membuat kebijakan yang profesional.

\section{GBHN dan Pembangunan Nasional}

GBHN sebagai pedoman program strategi pembangunan, secara sistematis berisi tujuan, landasan, azas, modal dasar, ruang lingkup dan pola pelaksanaan yang telah didesain sedemikian rupa dan memiliki legitimasi yang kuat. GBHN mencerminkan bahwa pembangunan nasional adalah pembangunan dari, oleh dan untuk rakyat, dilaksanakan pada semua aspek kehidupan bangsa yang meliputi aspek - aspek: politik, ekonomi, sosial budaya, dan aspek - aspek pertahanan keamanan dengan senantiasa harus merupakan perwujudan wawasan nusantara serta memperkukuh ketahanan nasional yang diselenggarakan dengan membangun bidang - bidang pembangunan yang diselaraskan dengan sasaran jangka panjang yang ingin diwujudkan.

Pembangunan nasional Indonesia merupakan pencerminan kehendak seluruh rakyat untuk terus menerus meningkatkan kesejahteraan dan kemakmuran rakyat Indonesia secara adil dan 
Aris Baharuddin, Maya Kasmita, Rudi Salam, Aspirasi Mahasiswa Fakultas Ilmu Sosial Universitas Negeri Makassar tentang Wacana GBHN ditinjau dalam Perspektif Ideologi Pembangunan |135

merata, serta mengembangkan kehidupan masyarakat dan penyelenggara negara yang maju dan demokratis berdasarkan Pancasila dan UUD 1945. Pembangunan nasional menghendaki keselarasan hubungan antara manusia dengan Tuhannya, antara manusia dengan sesama manusia, dan antara manusia dengan lingkungan alam sekitarnya.

\section{METODE PENELITIAN}

Penelitian ini berlokasi di kampus Fakultas Ilmu Sosial Universitas Negeri Makassar Gunung Sari baru Jl. AP. Pettarani Makassar. Fokus penelitian yang dikaji adalah kondisi dan tingkat aspirasi mahasiswa FIS UNM tentang wacana kembalinya GBHN sebagai pedoman dan pola dasar pembangunan nasional Indonesia. Adapun model/rancangan survey yang bersifat deskriptif kualitatif, yaitu menggambarkan dan mendiskripsikan data yang diperoleh dalam bentuk uraian dan tabel, persentasi. Teknik pengumpulan data yang digunakan adalah kuesioner, wawancara dan fokus group discussion, data/informan dikumpulkan dari 100 orang mahasiswa FIS UNM yang mewakili 5 jurusan/program studi yang ditarik secara proporsional sempling. Teknik analisis data yang digunakan adalah statistik deskriptif, yaitu menganalisis dan menafsir data faktual yang dideskripsikan kaitannya dengan permasalahan penelitian ini.

\section{HASIL DAN PEMBAHASAN}

\section{Kondisi aspirasi mahasiswa FIS UNM, tentang wacana pengembalian GBHN}

Respon sangat positif, menunjukkan kesungguhan hati dan pemahaman tentang; hakekat, tujuan, materi, manfaat, siapa yang sebaiknya menyusun, menetapkan, melaksanakan dan mempertanggung jawabkan GBHN. Gambaran pemahaman mahasiswa tentang siapa kelembagaan negara yang palin berhak menyusun/membuat GBHN, adalah sebagai berikut;

1. Majelis Permusyawaratan Rakyat Republik Indonesia (MPR RI), (sebanyak 65 responden / $71,42 \%)$

2. Dewan Perwakilan Rakyat Republik Indonesia (DPR RI) dan bersama Dewan Perwakilan Daerah Republik Indonesia (DPD RI) (sejumlah 15 responden /16,48\%)

3. Legislatif bersama Eksekutif (Presiden) (sejumlah 5 responden / 5,49\%)

4. Badan Perencanaan Pembangunan Nasional (BAPPENAS), (sejumlah 5 responden/ 5,49\%)

5. Dibuat/dibentuk oleh lembaga khusus atau tim kerja khusus (sejumlah 21 responden/ $23,07 \%$ )

\section{Tingkat aspirasi mahasiswa}

Hasil penelitian menunjukkan bahwa tingkat aspirasi mahasiswa dalam mendukung wacana dikembalikannya GBHN sebagai pedoman dan pola dasar pembangunan nasional Indonesia mencapai $91 \%$, hal ini menandai dan membuktikan kuatnya dukungan yang sangat 
136|Ad'ministrare, Vol. 3 No. 2, 2016

tinggi oleh mahasiswa fakultas ilmu sosial UNM untuk mengembalikan GBHN sebagai pedoman dan pola dasar pembangunan nasional Indonesia di masa mendatang.

\section{SIMPULAN}

Berdasarkan hasil dan pembahasan penelitian ini, maka dapat dikemukakan kesimpulan hasil penelitian sebagai berikut:

1. Kondisi aspirasi mahasiswa FIS UNM, tentang wacana pengembalian GBHN menunjukkan respon sangat positif, dan kesungguhan hati yang kuat, pemahaman yang mendalam tentang; hakekat, tujuan, materi, manfaat, siapa yang sebaiknya menyusun, menetapkan, melaksanakan dan mempertanggung jawabkan GBHN

2. Tingkat aspirasi mahasiswa FIS UNM dalam mendukung wacana dikembalikannya GBHN sebagai pedoman dan pola dasar pembangunan nasional Indonesia mencapai $91 \%$, hal ini menunjukkan dukungan yang sangat tinggi dan sangat berarti untuk mengembalikan GBHN sebagai pedoman dan pola dasar pembangunan nasional Indonesia masa kini dan masa mendatang.

\section{DAFTAR PUSTAKA}

Departemen Pendidikan dan Kebudayaan. 1998. UUD 45, P-4, GBHN dan Kewaspadaan Nasional (Bahan Penataran). Jakarta : Dirjen Dikti

Kompas. 2016. GBHN Membumikan Panduan. Kompas nomor 210 tahun ke-51, senin 1 Februari 2016.

Miftah Thoha. 2010. Birokrasi dan Politik di Indonesia. Jakarta : PT. RajaGrafindo Persada

Moleong, Lexy J. 1989. Metodologi Penelitian Kualitatif. Bandung : Remadja Karya.

Pusat Pembinaan dan Pengembangan Bahasa. 1975. Pedoman Umum Ejaan Bahasa Indonesia yang Disempurnakan. Jakarta : Departemen Pendidikan dan Kebudayaan Republik Indonesia.

Prawiroatmodjo Dendosurono. dkk, 1984. Pendidikan Kependudukan dan Lingkungan Hidup Suatu Pengantar. Jakarta : IKIP Jakarta

Saldi Irsa. 2016. Wacana Menghidupkan GBHN. Kompas nomor 190 tahun ke-51, selasa 12 Januari 2016.

Sugiyono. 2010. Metode Penelitian Kuantitatif Kualitatif dan R\&D. Bandung: CV.Alfabeta

Undang - undang RI Nomor 32 Tahun 2009 Tentang Perlindungan dan Pengelolaan Lingkungan Hidup. Bandung : Fermana

Undang - undang Dasar RI Tahun 1945 